\title{
Motivation and Retention of Teachers in a Family Business in Education A Case Study from South Asia
}

\author{
Umair Ahmed \\ Gulf University, Bahrain \\ umairahm@gmail.com \\ Waheed Ali Umrani \\ Sukkur IBA University, Pakistan \\ waheed.ali@iba-suk.edu.pk \\ Ajay A. Chauhan \\ President University, Indonesia \\ ajay@president.ac.id
}

\begin{abstract}
The case describes the professionalization, especially, the motivation and the commitment issues faced by Pioneers' School \& College, a private family-run business in an emerging Asian economy of Pakistan. The case sheds light on the initiatives taken by the School's Principal in this regard which resulted in the development of a unique teacher training program named, Teacher Nurturing Program (TNP). At the core, the case focused on the training and development aspect of human resource management to motivate and retain the good teachers and improve quality of teaching standards. The case provides an opportunity for students to reflect upon the need for schools like Pioneers` to competitively act and introduce employee training and learning programs to maintain teachers' motivation and commitment issues as well as to improve the school image through higher quality standards.
\end{abstract}

Keywords: Equity Human Resource Management, Training and Development, Training Nurturing Program, Training Design Process, TNP.

\section{Background}

\subsection{Angry Director}

It was a sunny afternoon of Friday the $2^{\text {nd }}$ of August, 2016 when Mr. Ikhlaque Ali Jeelani Shaikh was sitting in his office whereby, the discussion underwent regarding the drastic decrease in the teachers motivation and commitment. Mr. Shaikh, Managing Director of Pioneers`School \& College, had a heated debate with the Principal Mrs. Sonia Balouch; the Vice Principal and 4 Sectional Heads of the school. Throughout the entire week of Teachers` back to School, Mr. Shaikh seriously noticed poor motivation and lack of enthusiasm amongst the teachers which made him to realize that something need to be addressed on urgent 
grounds. He rejected all the justifications and explanations forwarded in the meeting. Mr. Shaikh asserted that if the situation remained the same, the school will lose in terms of quality which may further lead to teachers turnover. $\mathrm{He}$ advised the Principal, Mrs. Sonia Balouch to immediately investigate matter in consultation with the section heads and present in the next fortnightly meeting.

On the very next Monday morning, Mrs. Sonia called all the sectional heads during the school break time to discuss the matter further. The section heads were basically teachers as well as coordinators that were given the responsibility to look after matters pertaining to assigned class teachers. Mrs. Sonia expressed frustration as to why none of them noticed teachers' poor behaviors and motivation during the entire back to school week. All the section heads went apologetic but that was not acceptable to Mrs. Sonia. The question was what was needed to be done and how to address this issue. The meeting adjourned with the decision on calling teachers` meeting after two days. One of the section head was asked to put up a notice on the teachers information board inside staff common room.

\subsection{Teachers' Meeting}

As scheduled, the meeting started off at 14:00 hrs after school time and was chaired by Principal, Mrs. Sonia Balouch and Vice Principal Mr. Adeel Imtiaz. The VP commenced the meeting by recalling the Pioneers' aim which was to provide a healthy learning environment for better societal development. Upon this, Mr. Imtiaz explained that the school had a big aim to serve which was not possible without the support and efforts of school teachers. Thereby, he also shared the observations of the school management pertaining to drastic decline in teachers` motivation and enthusiasm. The teachers were also told that instead of returning back to school with higher motivation and commitment after a long summer vacation, the general observation was totally discouraging. "We therefore called up this meeting to provide you with an opportunity to discuss and resolve any issues" said Mrs. Sonia.

Surprisingly, no one uttered a single word and all the teachers kept starring at each other and it looked as if they wanted someone to start off and so to whom they could follow. The VP stood up and urged teachers to speak up and share their concerns; but the room went still quiet. Mrs. Sonia realized that teachers were reluctant to share in public and she immediately called all the section heads to take the teachers that they were assigned with in separate class rooms and ask them on a personal note.

On the next day, the sectional heads and VP gathered in Principal`s (Mrs. Sonia) office. Mrs. Sonia enquired everyone to share what they came to find out. The sectional heads mentioned that the teachers were happy to work with the school and also had no complaints regarding salary matters but they were concerned school expectations of 'quality education with a difference' and competitive nature of the students. The teachers also complained that the school only had traditional teaching facilities whereby there was a complete absence of training and skill development for teachers. The teachers had also underlined to sectional heads that majority of the schools in the locality had integrated technology and state of the art training and learning programs to facilitate teachers in maximizing 
students` learning. In short, the expectations were not equally satisfied with the learning resources provided for the teachers by the school management.

Mrs. Sonia clearly understood what the teachers were expecting. She also realized how this issue could potentially affect school`s reputation, teachers`motivation and student strength in the long run, if not considered seriously. Upon her return home, Mrs. Sonia discussed the entire situation with his husband, Mr. Shaikh upon which Mr. Shaikh said, "So, what is the solution then?" Mrs. Sonia replied, "Well we need to think over it and see what could be feasibly done." Mr. Shaikh in reply said, "Keep the financials in mind before making any decision". "Yes, I will and I have also asked the VP and sectional heads to discuss amongst themselves and come up with ideas for further action planning on the coming Friday", she replied back.

\section{Pioneer School and College}

\subsection{Background}

The Pioneers`School \& College a private family owned and operated School, situated in the Jamshoro city of Sindh, Pakistan was established by Mrs. Sonia Balouch, the Principal and her husband Mr. Shaikh, the Managing Director of the school. The school offered classes from Kindergarten up to $12^{\text {th }}$ standard (intermediate). The school also had Mr. Adeel Imtiaz, serving in the capacity of Vice Principal as shown in Figure 1 about the organization of the Pioneer School and College.

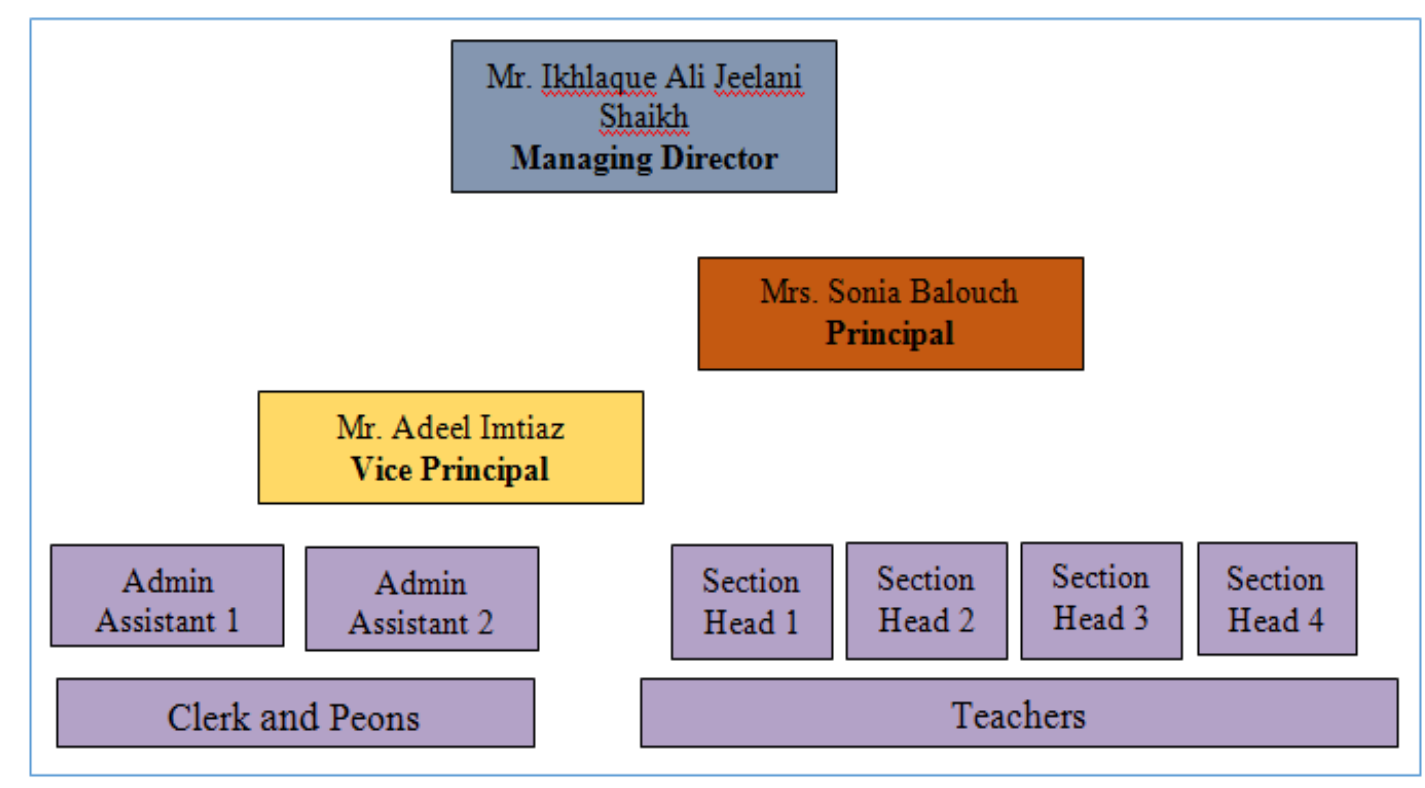

Figure 1. Organization Structure of Pioneers' School and College 
Apart from Principal and Managing Director, the school had 23 teachers and 4 sectional heads, who were also teachers and subject specialists. The strength of staff is shown in the Table 1.

Table 1. Staff Strength of Pioneers' School and College (December, 2016)

\begin{tabular}{|c|c|}
\hline Designation & Number of Personnel \\
\hline Principal & 1 \\
\hline Vice Principal & 1 \\
\hline Teachers & 23 \\
\hline Sectional heads & 4 \\
\hline Lab assistants & 2 \\
\hline Administrative Assistants & 2 \\
\hline Peons & 2 \\
\hline Cleaners & 3 \\
\hline Total & 38 \\
\hline
\end{tabular}

The school paid highly competitive salaries to motivate and retain staff and believes in providing quality education with merit and excellence.

As per Principal Mrs. Sonia, "At Pioneers', we aim to bring a positive change in the society through imparting education with a difference." This was the reason why the school has managed to attract a healthy number of students (Table 2) within a short span of 4 years.

Table 2. Student Strength of Pioneers' School and College (December, 2016)

\begin{tabular}{|c|c|}
\hline Class & Student Strength \\
\hline Nursery(A \& B) & 60 \\
\hline K. G (A \& B) & 56 \\
\hline Class 1 (A \& B) & 52 \\
\hline Class 2 (A \& B) & 47 \\
\hline Class 3 (A \& B) & 46 \\
\hline Class 5 (A \& B) & 63 \\
\hline Class 6 (A \& B) & 63 \\
\hline Class 7 (A \& B) & 62 \\
\hline Class 8 (A \& B) & 51 \\
\hline Class 9 & 44 \\
\hline Class 10 (Matric) & 44 \\
\hline Class 11 & 38 \\
\hline Class 12 (Intermediate) & 38 \\
\hline Total & 664 \\
\hline
\end{tabular}




\subsection{History}

Mr. Shaikh, the founder and the Managing Director, came from a learned family background. His father was also an educationist by profession with immense passion and love for teaching and learning. Mr. Ikhlaque Ali Jeelani Shaikh, was a 38-year old guy who was the owner and managing director of the school. Alongside, he also owned and personally run a major convenience super store in the city center.

Mr. Shaikh spent most of his time at the store whereby, he occasionally visited school to look into its financial matters. Mr. Shaikh, he was also the central decision-making authority for major administrative matters of the school. Mrs. Sonia served as the Principal and was responsible to look after the rest of the administrative matters.

Pertaining to education, Mr. Shaikh holds master's degree in educational leadership. Similarly, his wife and also as Principal, Mrs. Sonia was also a learned individual with decades of experience in teaching and school administration. She was enthusiastic about student learning and always strives to bring enhancements in this regard. This husband and wife duo started the Pioneers' School and College in 2012 in Jamshoro, a small town about 18 kilometers from Hyderabad in Sindh province of Pakistan and about 155 kilometers from Karachi, which is the most populous city of Pakistan.

Jamshoro is the entrance to the Indus Valley, globally known for its civilization and rich cultural heritage. The Ranikot Fort is located 40 kilometers to the north of the campus. Ranikot Fort is also known as "The Great Wall of Sindh" and believed to be the world's largest fort with a circumference of approximately 26 kilometers.

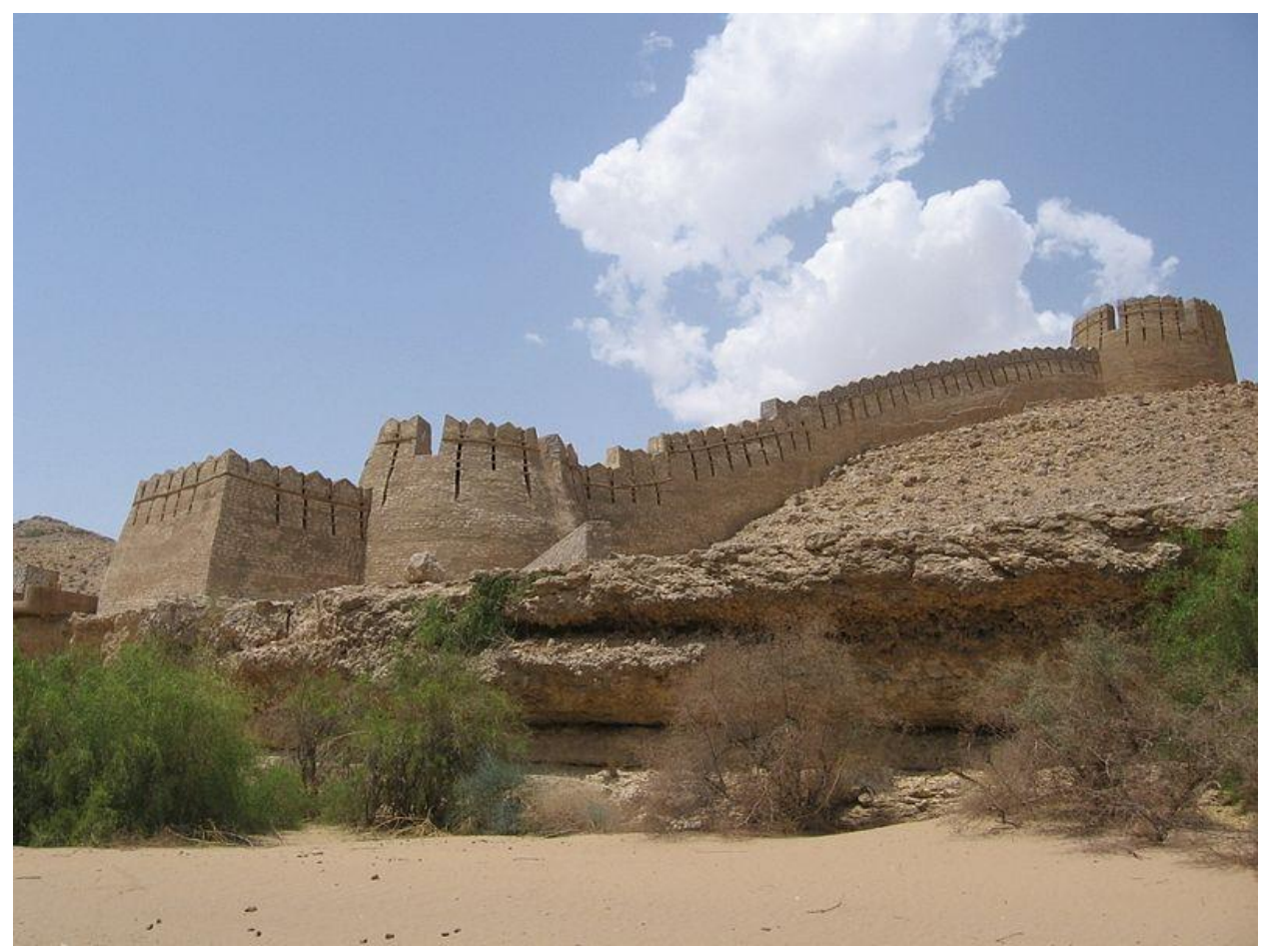

Figure 2. Ranikot - The Great Wall of Sindh 
Archaeologists point to 17th century as its time of first construction but now Sindh archaeologists agree that some of the present structure was reconstructed by Mir Karam Ali Khan Talpur Baloch and his brother Mir Murad Ali Baloch in 1812 at a cost of 1.2 million undivided Indian rupees (Ali, 2011). Since 1993, it has been on the tentative list of UNESCO World Heritage Sites (Ali, 2011). Mancher Lake, the largest fresh water lake in the region, is situated to the west north west of Sehwan. Travelling about 150 kilometers north through the Indus plains one reaches the world famous site of Mohan-jo-Daro, the most important archeological discovery of the Valley.

\subsection{Vision and Mission of Pioneers' School and College}

The school was set up here because Jamshoro is the educational hub of Sindh. The vision and mission of the Pioneers' were set up in the beginning itself and are the guide to all the future activities of the school.

\section{Vision}

"To become a leading school in the region"

The vision at Pioneers is to become a leading school in the region through providing up-to-date knowledge and skills for life-long development. The vision is to also contribute at the national level with its core values: knowledge, respect, inclusion and excellence.

\section{Mission}

"To develop the future human capital of the country through an active and creative learning environment"

The Pioneers' mission is to develop the human capital of the country by providing an active and creative learning environment. There is a stress on providing enriched learning programs, taught by highly effective teachers and engaging resources to prepare leaders for the future.

\section{Core Values}

The Pioneers' School and College believes in core values to guide all the teaching and other activities in the institution.

- Knowledge

- Respect

- Inclusion

- Excellence 


\subsection{Competitive Position}

As a private school, Pioneers has several competitive rivals in town. Notably, the school holds a strong competitive position in the Jamshoro city. However, it had has a major competition when it comes to attracting students from the nearby city (Hyderabad) from schools like City School, Beacon House School and Foundation Public School. For Pioneers it is essential to remain actively competitive in all aspects since the rival establishments are major chains of school with strong financial position. This could turn out to be a major threat for Pioneers as well especially in relation to retaining good teachers.

\section{Case Diagnosis and Solution}

\subsection{Diagnosis}

The school offers teachers with conventional teaching resources such as black board, practice sheets and chalks. Teachers`Back to School is a week-long program that runs one week prior to the normal school opening dates, every year. The back to school week is basically a platform for teachers to come to the school for few hours every day, the entire week to prepare notes and teaching material for their respective classes.

On Friday, Mr. Imtiaz (Vice Principal) along with 4 sectional heads reported in her office for further discussion. Mrs. Sonia started by saying, "Maintaining quality in education and teaching staff is a tough job and requires working with a common mindset and focus. I am glad that we have managed to highlight the problems and teachers` concerns but the real task for all of us now is to explore ways of resolving them. Therefore, what are your suggestions?"

The Vice Principal added that, "The teachers have predominantly complained about NO training and learning opportunities which will cost time and money and therefore we have to look into our financials as well." Mrs. Sonia seemed in agreement with the remarks of VP and responded, "You are correct but we got to sort out both the issues, one way or the other. Let us work it out together and develop a plan for Mr. Shaikh to review on the next week's fortnightly meeting," said Mrs. Sonia.

\subsection{Solution Process}

On the next Friday, Mr. Shaikh arrived for the fortnightly meeting at the school and Mrs. Sonia along with his management team had developed a comprehensive plan for discussion. Right at the start of the meeting, Mr. Shaikh said that what the progress regarding teachers` issues upon which Mrs. Sonia was asked the Vice Principal to mention the major problems. Mr. Shaikh was told that teachers were concerned about unavailability training initiatives at the school. She also highlighted and accepted the fact that school has not been providing any sort of teacher trainings since the beginning because of which, less experienced teachers were encountering more problems. 
After a brief sigh, Mr. Shaikh said, "So, let me hear what you people have planned." Upon this, Mrs. Sonia mentioned that she along with the sectional heads have come up with a three stage teachers training plan. According to it, the first stage caters to teachers` training whereby, training need analysis would be conducted to acquire information on key areas/subjects/ and/or topics where the teachers require to be trained. Based on the need analysis results, a detailed plan would be designed further course of action. "We will have to sit and decide further once we reach to this stage," added Mrs. Sonia.

Mr. Shaikh said, "OK, so how much time will it possibly require?" "May be another two weeks or so but, not sure," replied Mrs. Sonia. Mr Shaikh said in reply, "OK, start working on it and let me know what comes up but please make sure that the plan is financially feasible and quick in implementation; we cannot just hold issues for long".

Mrs. Sonia went very excited to receive the go-ahead signal. She clearly had the idea that it was not an easy task to come up with a strategy or plan to address the training issue but in a way, she was also clear what to focus ahead. Though she was super excited yet still, she realized the major responsibility she has taken up on her shoulders.

Mrs. Sonia in consultation with the Vice Principal and sectional heads developed a plan that she named as TNP- Teacher Nurturing Program as shown in Figure 3.

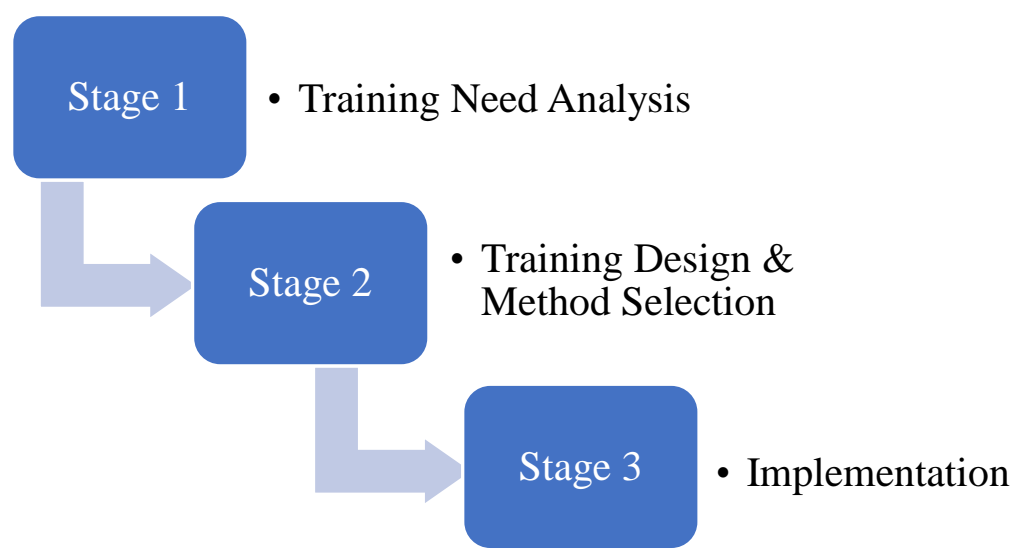

Figure 3. TNP - Teacher Nurturing Program

\section{Teacher Nurturing Program (TNP)}

\subsection{Stage 1: Training Need Analysis}

As per the proposed program, Mrs. Sonia developed a basic need analysis questionnaire and asked the sectional heads to get every teacher to fill it. The questionnaire was dispersed asking teachers to mention the subjects they taught; skills required; areas they wished to improve and specific trainings that they desired to receive. Alongside, Mrs. Sonia also met a few teachers in person to informally discuss their concerns. She mentioned, "I deliberately did so in order to make our teachers feel that the management cares for them and is concerned 
about their development." Whilst analyzing and compiling the need analysis results, she realized that majority of the teachers expressed sincere aspiration to receive training on several things, which were:

- Soft skills such as classroom management, student handling, teaching and learning, student behavioral management.

- Technology in Teaching and the latest software(s) and tools used in teaching.

- Awareness on contemporary pedagogical methodologies.

Moreover, the analysis also bought up few teachers' requests, desiring for interactive subject-specific trainings such as Training on Teaching Mathematics to ninth and tenth grade students etcetera. Mrs. Sonia already had this in her knowledge as she came to know some of the prominent schools in the same region were offering subject-focused and technology based training programs along with motivational workshops to boost teachers' personal and professional skills and capabilities.

\subsection{Stage 2: Training Design and Methodology}

Once the need analysis results were finalized, the next task for Mrs. Sonia as per the TNP- Teacher Nurturing Program was to formulate action plan for training conduct. She certainly knew about off-the-job and on-the-job training options but was quite confused as to which of the methodology would be both effective and efficient for the school.

Whilst keeping the instructions of his husband, Mr. Shaikh, beforehand, Mrs. Sonia had to propose a strategy that was cost effective as well as strategically beneficial. This was why she realized that sending all teachers away from the school premises for training was neither financially feasible nor logistically possible.

Accordingly, calling outside trainers for any program seemed feasible however, majority of the training consultants were based in Karachi city which was approximately 140 kilometers away from Jamshoro city. Therefore, the consultants asked for hefty sum amounts when requested to travel to Jamshoro for training. In the meanwhile, Mrs. Sonia came to know that there were certain well reputed teacher training bodies that frequently conducted training programs through open enrollment process and also offer healthy group discounts and member schools. But again, it was neither logistically feasible nor financially possible for the Pioneers` to send all of its teachers for such a training program as majority of such training companies were again based in Karachi or Lahore.

The situation got a bit confusing for Mrs. Sonia; she kept discussing this with the Vice Principal and sectional heads. Finally, Mrs. Sonia decided to go for a mix of both the training approaches for the TNP-Teacher Nurturing Program.

Conclusively, they decided to propose Mr. Shaikh that the school would seek membership of a reputed teacher training body in Karachi and would send oneteacher from of every subject area for training. The school then would potentially get the benefit from group discounts and upon their return, the teachers would be required to replicate the training programs for the rest of the school teachers in the area which would eventually result in training all the teachers both effectively and 
efficiently. The Plan also proposed Mr. Imtiaz (Vice Principal) to look into travelling, loading and accommodation matters of teachers in Karachi to propose Mr. Shaikh. After all the 2-week long hard work, Mrs. Sonia was firm confident to convince Mr. Shaikh with the training proposal.

\subsection{Stage 3: Implementation}

On the next fortnightly meeting, Mrs. Sonia discussed the proposed findings and suggestions with Mr. Shaikh along with the training need analysis results conducted based on the formulated Teachers` Nurturing Program (TNP). Based on the highlights and results of the training need analysis, Mrs. Sonia and her team told Mr. Shaikh that for the purpose of implementation of TNP, two-phase plan was devised. Therein, phase 1-one proposed and recommended taking teachers for core soft skills training to boost their motivation, confidence and classroom management capabilities. In parallel, the phase also mentioned subject based training programs of the proposed TNP plan. Concurrently, the phase 2 was proposed with programs specifically focusing on technology and its usage in classes. The plan proposed to implement entire phase 1 over the next 6 months and see how it would work.

\section{Phase 1:}

- Classroom Management

- Effective Teaching And Behavioral Management

- Subject Focused Training Programs

Phase 2:

- Training on Latest Teaching Methodologies

- Training on Technology in Teaching

Mrs. Sonia mentioned Mr. Shaikh that initially the school may focus on Phase 1 of the plan and see how it would go. In addition, she also underlined that the teachers going for training would be tagged as certified teacher trainers for the school. This would make the school self-sufficient in this domain. Hence, within a span of 1 year, the school would be resourceful enough to train its own teachers, Mrs. Sonia asserted. "The plan therefore will strategically benefit us in the long run in a cost-effective manner", said Mrs. Sonia. She also proposed for some additional compensation to teachers going to training in order to boost their morale and commitment.

Taking the discussion further on the TNP, Mr. Imtiaz added that the training programs would actively enhance skill levels of the teachers in terms of teaching and classroom management. The training programs would significantly boost their confidence and commitment towards the profession and school. The training programs would also help teachers in providing quality education whilst meeting the $21^{\text {st }}$ century teaching standards. Moreover, there would be higher chances of the students securing distinctions in board and final examinations. Above all, this 
would also support the school in enhancing the school image, thus resulting in securing a competitive position in the market.

"So, what will be the cost for all these training initiatives?" said Mr. Shaikh. "Yes, we have worked on it as well", said Mrs. Sonia. She added, "We are proposing two approaches in this regard whereby, we provide transportation to teachers to attend training on a daily basis or otherwise, arrange accommodation for them in Karachi." The meeting also shared possible breakdown of expenses for both the situations as shown in Tables below.

Table 3(a). Estimated Expense Plan A (Teachers Staying in Karachi)

\begin{tabular}{|l|c|r|}
\hline Description & Cost & $\begin{array}{r}\text { Total } \\
\text { (In Rs.) }\end{array}$ \\
\hline Membership (One Time) & Rs. 12,000 & 12,000 \\
\hline $\begin{array}{l}\text { Discounted Training Fee- } \\
\text { 10\%2 days }\end{array}$ & Rs. 13,500 & \\
\hline $\begin{array}{l}\text { Total Teachers going for } \\
\text { Training (Proposed) }\end{array}$ & 4 X13,500 & 54,000 \\
\hline Travelling & $\begin{array}{c}550 \text { X 4 persons X } \\
\text { 2 Days }\end{array}$ & 4,400 \\
\hline Travelling Meal Allowance & $\begin{array}{c}\text { Rs. 800 } \\
\text { (2 meals) X 4 }\end{array}$ & 6,400 \\
\hline Accommodation (1 Day) & $\begin{array}{c}\text { Rs. 3900 (Twin } \\
\text { Room) }\end{array}$ & 7,800 \\
\hline \multicolumn{2}{|c|}{ Total } \\
\hline
\end{tabular}

Table 3(b). Estimated Expense Plan B (Teachers Returning Back Every Day)

\begin{tabular}{|l|c|r|}
\hline Description & Cost & Total (In Rs.) \\
\hline Membership (One Time) & Rs. 12,000 & 12,000 \\
\hline $\begin{array}{l}\text { Discounted Training Fee- } \\
10 \% \text { 2 days }\end{array}$ & Rs. 13,500 & 54,000 \\
\hline $\begin{array}{l}\text { Total Teachers going for } \\
\text { Training (Proposed) }\end{array}$ & 4 X13,500 & 16,000 \\
\hline Travelling (Taxi) & $\begin{array}{c}\text { Rs 4,000 (Return) } \\
\text { X 2 Days }\end{array}$ & 3,200 \\
\hline $\begin{array}{l}\text { Travelling Meal } \\
\text { Allowance }\end{array}$ & $\begin{array}{c}\text { Rs. 400 } \\
\text { Person X 2 Days } 4\end{array}$ & 85,200 \\
\hline \multicolumn{2}{|c|}{ Total } \\
\hline
\end{tabular}

Mrs. Sonia contended that, "Based on the monthly income and expense sheet (Refer Exhibit V), the school can responsively afford this cost for the responsive implementation of Phase 1 of the TNP”. She also reminded Mr. Shaikh again that, 
the teachers would replicate the learning for other teachers upon their return, twice to assure responsive transfer of training. Overall, the whole process may take up to 2 months approximately after which, the school would send another group of teachers for the next program. Mrs. Sonia repeatedly assured Mr. Shaikh that since all this requires a considerable investment, the school would therefore not proceed to any other training events until and unless, the prior learning was effectively found implemented and practiced.

Mr. Shaikh heard the entire proposed TNP and its implementation plan with concentration but seemed undecided. Though he found nothing much to object to argue upon yet still, he seemed having mixed feelings. "I need time to think and decide before any further progress", said Mr. Shaikh.

\section{Case Questions}

The objective of this case is to understand training phenomenon and its significance and to develop comprehension among the students concerning the viability of training for professional as well as business development. The students could learn to explore critical aspects of training process and implementation.

The questions that need to be answered after reading the case (could be the student assignments) are:

1. Was there a need for teacher training at Pioneers?

2. Would it be of value for the teachers at Pioneers?

3. Was the training need analysis process carried on by Pioneers, properly? Was the involvement of sectional heads a right decision? Could it lead to any potential bias or not?

4. Was the program financially feasible for Pioneers to carry on in the long run? The students could make use of information in the Appendix at the end.

5. Was TNP a worthy of consideration in the case of Pioneers and how its effectiveness be ascertained?

6. Should Mr. Shaikh, allow the school to implement TNP? If yes, which of the two options should he decide for implementation in the Phase 1 ?

7. Could there be a better alternative for Pioneers? 


\section{Appendix}

Monthly Income \& Expense Sheet

\begin{tabular}{|c|c|c|}
\hline Description & Amount & Total \\
\hline \multicolumn{3}{|l|}{ Students fee } \\
\hline Nur-Class VIII & Rs $1500 \times 500$ & Rs. 75,0000 \\
\hline Class IX \& X & Rs. 2000 X 88 & Rs. 176,000 \\
\hline Class XI \& XII & Rs. 2300 X 76 & Rs. 174,800 \\
\hline Salaries & Total & 1100,800 \\
\hline Teachers Salary (Full Time) & Rs. 18,000 X 19 & Rs. 342,000 \\
\hline Teachers Salary (Part Time) & Rs. $11,000 \times 4$ & Rs. 44,000 \\
\hline Section Heads & Rs. $25,500 \times 4$ & Rs. 102,000 \\
\hline Lab Assistants & Rs. $15,000 \times 2$ & Rs. 30,000 \\
\hline Administrative Assistants & Rs. $15,000 \times 2$ & Rs. 30,000 \\
\hline Peons & Rs. 9,500 X 2 & Rs. 19,000 \\
\hline Cleaners & Rs. 6200 X 3 & Rs. 18,600 \\
\hline Statutory Expenses & Total & 585,600 \\
\hline \multicolumn{3}{|l|}{ Bills (approx.) } \\
\hline Electricity & $\begin{array}{r}\text { Rs. 55,000 (+/- } \\
10 \%)\end{array}$ & Rs. 55,000 \\
\hline Water & Rs. 1,100 & Rs. 1,100 \\
\hline Council Tax & Rs. 1,560 & Rs. 1,560 \\
\hline \multirow[t]{2}{*}{ Union Fee } & Rs. 180 & Rs. 180 \\
\hline & Total & 57,840 \\
\hline \multicolumn{3}{|l|}{ Others } \\
\hline \multirow[t]{3}{*}{$\begin{array}{l}\text { Maintenance } \\
\text { (monthly) }\end{array}$} & $\begin{array}{r}2500-5000 \\
\text { (monthly) }\end{array}$ & Rs. 2500 \\
\hline & Total Expenses & Rs. 645,940 \\
\hline & Income-Expenses & Rs. $\mathbf{4 5 4 , 8 6 0}$ \\
\hline
\end{tabular}




\section{References}

Ali, S. M. (2011). The Forts of Pakistan. Pakistaniaat: A Journal of Pakistan Studies, 3(2), 124-50.

Ondaatje, C. (1996). Sindh revisited: a journey in the footsteps of Captain Sir Richard Burton: 1842-1849, the India years. London: Harper Collins. 